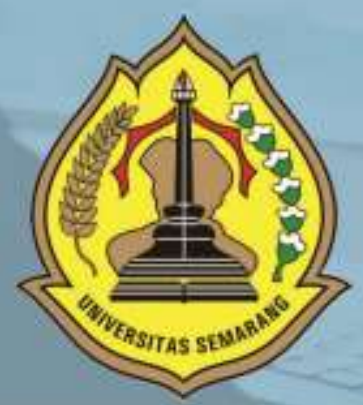

PENGARUH WORK FAMILY CONFLICT, STRES KERJA DAN KEPEMIMPINAN TERHADAP TURNOVER INTENTION KARYAWAN (STUDI PADA SELURUH KARYAWAN BAGIAN PLANNING PRODUCTION AND INVENTORY CONTROL PT. PARKLAND WORLD INDONESIA JEPARA

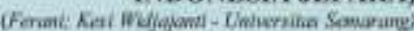

STUDI SOFT SKILL LULUSAN PENDIDIKAN KEJURUAN DI TEMPAT KERJA

Whort-Chiversikio Semorang

ANALISIS IINGKUNGAN INTERNAL DAN EKSTERNAL, PADA UKM PREMIUM PLUS LAUNDRY CABANG MULAWARMAN SEMARANG

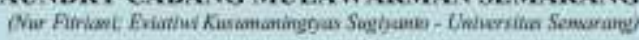

FAKTOR-FAKTOR YANG MEMPENGARUHI PERTIMBANGAN TINGKAT MATERIALITAS AUDIT

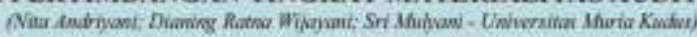

MANAJEMEN LABA DAN FAKTOR-FAKTOR YANG MEMPENGARUHINYA (STUDI EMPIRIS PADA PERUSAHAN MANUFAKTUR DI BEI)

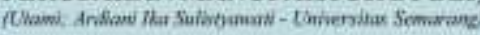

PENDAPATAN ASLI DAERAH, DANA PERIMBANGAN, DAN SISA LEBIH PEMBIAYAAN ANGGARAN TERHADAP PENGALOKASIAN BELANJA MODAL: STUDI PADA KABUPATEN/KOTA DI PROVINSI JAWA TENGAH

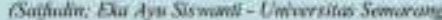

PERSEPSI PENGGUNA JASA TRANS JATENG TERHADAP KUALITAS PELAYANAN ANGKUTAN AGLOMERASI PERKOTAAN TRANS

JATENG

(Studi Kasus Trans Jateng Koridor I Semarang (Tawang) - Bawen)

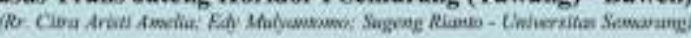

WORTHLESSNESS IS A POWER: MENGAPA ORANG BERSEDIA MENARUH UANG DI APLIKASI GO-PAY

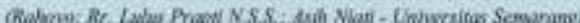

ANALISIS PENGARUH KUALITAS PRODUK, PERSEPSI HARGA, DAN PROMOSI TERHADAP KEPUTUSAN PEMBEIIAN WELLBLUE AL KALINE WATER PITCHER

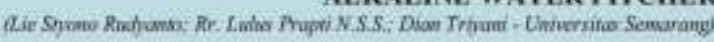

STRATEGI PEMASARAN UNTUK MENINGKATKAN VOLUME PENJUALAN (STUDI KASUS PADA SHOFA CATERING)

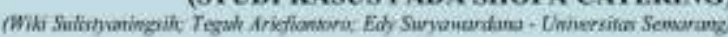

PENGARUH CITRA MEREK, PERSEPSI HARGA, DAN KUALITAS PRODUK TERHADAP KEPUTUSAN PEMBELIAN SEPATU OLAH RAGA MEREK ADIDAS

(Studi di Kota Semarang)

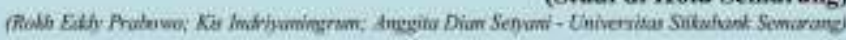

PENGARUH KEMUDAHAN TERHADAP KEPUTUSAN MENGGUNAKAN E-BANKING PADA BNI 46 KC KARANGAYU SEMARANG DENGAN MINAT NASABAH DAN KEPERCAYAAN SEBAGAI VARIABEL. MEDIASI

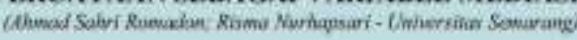

PENELITLAN KEBERLANGSUNGAN USAHA ARDANI INDONESIA SEBAGAI UMKM BERBASIS INDUSTRI KREATIF

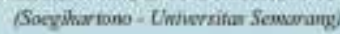

STRATEGI PELAYANAN BUS RAPID TRANSIT (BRT) TRANS SEMARANG

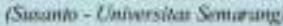

ANALISIS PENGARUH KEPEMIMPINAN, STRES KERJA, DAN LINGKUNGAN KERJA TERHADAP KINERJA KARYAWAN BAGIAN PRODUKSI SEWING PT. SAMWON BUSANA INDONESIA SEMARANG

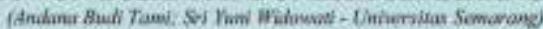




\section{DESKRIPSI}

Majalah IImiah Solusi Mengkaji

Masalah-Masalah Sosial,

Ekonomi dan Bisnis

\section{KETERANGAN TERBIT}

Terbit Pertama Kali Juli 2002

dan SelanjutnyaTerbit Tiga Bulan

Sekali (Januari, April, Juli dan

Oktober)

\section{PENERBIT}

Fakultas Ekonomi USM

\section{ALAMAT PENERBIT}

JL. Soekarno Hatta Semarang

Telp. 024-6702757 Fax. 024-6702272

\section{PENGELOLA}

Editor in Chief : Yohanes Suhardjo, SE, M.Si., Ak, CA Vice Editor Chief : Sugeng Rianto, SE, MM

Managing Editor: Edy Suryawardana, SE, MM

Secretary of Managing Editor : Asih Niati, SE, MM

Administration \& Circulation :

Citra Rizkiana, SE, MM

Layout \& Typesetting : M Burhan Hanif S.Kom, M.Kom

Board of Editors:

1. Prof. Dr. Ir. Kesi Widjajanti, SE, MM (USM)

2. Prof. Drs. Mohammad Nasir, Msi, Ph.D, AK. (USM)

3. Prof. Supramono SE, MBA, DBA (UKSW)

4. Prof. Drs. H. Imam Ghozali, M.Com, Akt, PhD (UNDIP)

5. Prof. Dr. Agus Suroso, MS (UNSOED)

6. Prof. Dr. Widodo, SE, M.Si (UNISSULA)

7. Prof. Dr. Dra. Sulastri, ME, M.Kom (UNSRI)

8. Dr. Ardiani Ika S, SE, MM, Ak, CA, CPA (USM)

\section{KATA PENGANTAR}

Sungguh merupakan kebahagiaan tersendiri bagi kami, takala kami dapat hadir rutin setiap tiga bulan sekali untuk saling bertukar pikiran mengenai hal-hal baru dibidang sosial, ekonomi dan bisnis.

Pada kesempatan ini penerbit menyampaikan terima kasih kepada semua pihak yang telah mengirimkan artikel-artikelnya. Penerbit akan membuka kesempatan seluas-luasnya bagi seluruh kalangan akademisi maupun praktisi baik dari dalam maupun luar Universitas Semarang untuk mempublikasikan karya ilmiahnya.

Penerbitan majalah ilmiah "SOLUSI" kali ini menghadirkan 15 (Lima Belas) artikel yang kami anggap layak untuk diterbitkan, dengan harapan dapat menjadi tambahan referensi bagi para pembaca dan menjadi sumbangan pengembangan persemaian khasanah pengetahuan dibidang sosial, ekonomi dan bisnis.

Akhir kata semoga majalah ilmiah "SOLUSI" dapat memberi manfaat yang sebesar-besarnya.

Hormat Kami 


\section{DAFTAR ISI}

PENGARUH WORK FAMILY CONFLICT, STRES KERJA DAN KEPEMIMPINAN TERHADAP TURNOVER INTENTION KARYAWAN (STUDI PADA SELURUH KARYAWAN BAGIAN PLANNING PRODUCTION AND INVENTORY CONTROL PT. PARKLAND WORLD INDONESIA JEPARA)

(Ferani; Kesi Widjajanti - Universitas Semarang)

STUDI SOFT SKILL LULUSAN PENDIDIKAN KEJURUAN DI TEMPAT KERJA

(Albert - Universitas Semarang)...

ANALISIS LINGKUNGAN INTERNAL DAN EKSTERNAL PADA UKM PREMIUM PLUS

LAUNDRY CABANG MULAWARMAN SEMARANG

(Nur Fitriani; Eviatiwi Kusumaningtyas Sugiyanto - Universitas Semarang)

FAKTOR-FAKTOR YANG MEMPENGARUHI PERTIMBANGAN TINGKAT

MATERIALITAS AUDIT

(Nita Andriyani; Dianing Ratna Wijayani; Sri Mulyani - Universitas Muria Kudus).

MANAJEMEN LABA DAN FAKTOR-FAKTOR YANG MEMPENGARUHINYA

(STUDI EMPIRIS PADA PERUSAHAN MANUFAKTUR DI BEI)

(Utami; Ardiani Ika Sulistyawati - Universitas Semarang)

PENDAPATAN ASLI DAERAH, DANA PERIMBANGAN, DAN SISA LEBIH PEMBIAYAAN ANGGARAN TERHADAP PENGALOKASIAN BELANJA MODAL: STUDI PADA

KABUPATEN/KOTA DI PROVINSI JAWA TENGAH

(Saifudin; Eka Ayu Siswanti - Universitas Semarang).

PERSEPSI PENGGUNA JASA TRANS JATENG TERHADAP KUALITAS PELAYANAN ANGKUTAN AGLOMERASI PERKOTAAN TRANS JATENG

(Studi Kasus Trans Jateng Koridor I Semarang (Tawang) - Bawen)

(Rr. Citra Aristi Amelia; Edy Mulyantomo; Sugeng Rianto - Universitas Semarang)

WORTHLESSNESS IS A POWER: MENGAPA ORANG BERSEDIA MENARUH UANG DI APLIKASI GO-PAY

(Rahoyo; Rr. Lulus Prapti N.S.S.; Asih Niati - Universitas Semarang).

ANALISIS PENGARUH KUALITAS PRODUK, PERSEPSI HARGA, DAN PROMOSI TERHADAP KEPUTUSAN PEMBELIAN WELLBLUE ALKALINE WATER PITCHER

STRATEGI PEMASARAN UNTUK MENINGKATKAN VOLUME PENJUALAN (STUDI KASUS PADA SHOFA CATERING)

(Wiki Sulistyaningsih; Teguh Ariefiantoro; Edy Suryawardana - Universitas Semarang)

PENGARUH CITRA MEREK, PERSEPSI HARGA, DAN KUALITAS PRODUK TERHADAP KEPUTUSAN PEMBELIAN SEPATU OLAH RAGA MEREK ADIDAS

(Studi di Kota Semarang)

(Rokh Eddy Prabowo; Kis Indriyaningrum; Anggita Dian Setyani - Universitas Stikubank Semarang) .121

PENGARUH KEMUDAHAN TERHADAP KEPUTUSAN MENGGUNAKAN E-BANKING PADA BNI 46 KC KARANGAYU SEMARANG DENGAN MINAT NASABAH DAN KEPERCAYAAN SEBAGAI VARIABEL MEDIASI

(Ahmad Sahri Romadon; Risma Nurhapsari - Universitas Semarang) 
PENELITIAN KEBERLANGSUNGAN USAHA ARDANI INDONESIA SEBAGAI UMKM BERBASIS INDUSTRI KREATIF

(Soegihartono - Universitas Semarang)

STRATEGI PELAYANAN BUS RAPID TRANSIT (BRT) TRANS SEMARANG

(Susanto - Universitas Semarang).....

ANALISIS PENGARUH KEPEMIMPINAN, STRES KERJA, DAN LINGKUNGAN KERJA TERHADAP KINERJA KARYAWAN BAGIAN PRODUKSI SEWING PT. SAMWON BUSANA INDONESIA SEMARANG

(Andana Budi Tami; Sri Yuni Widowati - Universitas Semarang). 


\title{
PENDAPATAN ASLI DAERAH, DANA PERIMBANGAN, DAN SISA LEBIH PEMBIAYAAN ANGGARAN TERHADAP PENGALOKASIAN BELANJA MODAL: STUDI PADA KABUPATEN/KOTA DI PROVINSI JAWA TENGAH
}

\author{
Saifudin ${ }^{1}$ \\ Eka Ayu Siswanti ${ }^{2}$ \\ saifudin@usm.ac.id ${ }^{1}$ \\ ayueeka27@gmail.com²
}

Fakultas Ekonomi Universitas Semarang

Diterima: Agustus 2020, Disetujui: September 2020, Dipublikasikan: Oktober 2020

\begin{abstract}
This study is aimed to test the effect of Local Government Revenue (PAD), Transfer Funds, and Surplus of Budget Financing in allocating Capital Expenditure in districts/cities in Central Java Province. Population in this study is all local governments in Central Java Province for year of 2009 - 2013. In Central Java Province, there are 35 local governments which consist of 26 districts and 9 cities. The 35 local governments were observed for 5 periods so that the total observations are 175 observations. The data used is Budget Realisation Statements of districts/cities in Central Java Province which is sourced from DJPK Ministry of Finance. Analytical method used is double linear regression. The result of this research shows that either in partial, Local Government Revenue (PAD), Transfer Funds, and Surplus of Budget Financing have influence to Captal Expenditure.
\end{abstract}

Keywords: Local Government Revenue (PAD), Transfer Funds, Surplus of Budget Financing, Captal Expenditure

\begin{abstract}
ABSTRAK
Penelitian ini bertujuan untuk menguji pengaruh Pendapatan Asli Daerah, Dana Perimbangan, dan Sisa Lebih Pembiayaan Anggaran terhadap pengalokasian belanja modal pada Kabupaten/Kota di Provinsi Jawa Tengah. Populasi dalam penelitian ini adalah seluruh kabupaten/kota di Propinsi Jawa Tengah tahun 2009-2013. Dimana Provinsi Jawa Tengah terdapat 35 pemerintahan daerah yang terdiri dari 26 pemerintahan kabupaten dan 9 pemerintahan kota. Selanjutnya dari 35 kabupaten/kota akan diamati selama 5 periode sehingga jumlah pengamatan sebanyak 175 pengamatan. Data yang digunakan adalah Laporan Realisasi Anggaran kabupaten/kota di Provinsi Jawa Tengah yang bersumber dari DJPK Departemen Keuangan . Metode analisis yang digunakan adalah regresi linear berganda. Hasil penelitian menunjukkan bahwa secara parsial Pendapatan Asli Daerah (PAD), Dana Perimbangan, dan Sisa Lebih Pembiayaan Anggaran berpengruh terhadap Belanja Modal.
\end{abstract}


Kata Kunci : Pendapatan Asli Daerah, Dana Perimbangan, Sisa Lebih Pembiayaan Anggaran, Belanja Modal.

\section{PENDAHULUAN}

Dengan diberlakukannya Undang-Undang No. 22 Tahun 1999, yang kemudian diubah dengan UU No. 32 Tahun 2004 tentang Pemerintahan Daerah, merubah bentuk pemerintahan yang sentralisasi menjadi struktur desentralisasi. Desentralisasi adalah penyerahan wewenang pemerintahan oleh Pemerintah kepada daerah otonom untuk mengatur dan mengurus urusan pemerintahan dalam sistem Negara Kesatuan Republik Indonesia. Pemerintah Daerah mempunyai wewenang dalam mengurus daerahnya dengan sedikit campur tangan Pemerintah Pusat. Dengan demikian Pemerintah Daerah memiliki hak dan kewenangan untuk mengelola dan menggunakan sumber - sumber keuangan atau anggaran yang dimiliki sesuai dengan kebutuhan dan aspirasi masyarakat yang berkembang di daerah.

Anggaran merupakan rencana kerja keuangan yang dibuat secara terus menerus untuk membangun suatu daerah. Dalam pemerintahan, anggaran digunakan untuk membangun suatu daerah agar menjadi daerah yang maju dan mandiri. Setiap tahun, pejabat negara membuat anggaran kebutuhan negara yang kemudian dikenal dengan Anggaran Pendapatan dan Belanja Negara (APBN). Tidak hanya pejabat negara yang membuat anggaran setiap tahunnya, tetapi pejabat daerah juga membuat anggaran yang digunakan untuk pembangunan daerah yang kemudian disebut dengan Anggaran Pendapatan dan Belanja Daerah (APBD). Penyusunan APBD didasarkan pada kebutuhan daerah untuk meningkatkan kualitas daerahnya. Salah satu yang dilakukan pemerintah daerah untuk meningkatkan kualitas daerahnya yaitu dengan belanja.

Pemerintah Daerah memiliki kewenangan untuk menentukan alokasi sumber daya yang dimiliki untuk belanja - belanja daerah dengan menganut asas kepatuhan, kebutuhan, dan kemampuan daerah yang tercantum dalam anggaran daerah. Pengalokasian sumber daya ke dalam anggaran belanja modal merupakan sebuah proses yang sarat dengan kepentingan-kepentingan politis. Anggaran ini sebenarnya dimaksudkan untuk memenuhi kebutuhan publik akan sarana dan prasarana umum yang disediakan oleh pemerintah daerah. Namun, adanya kepentingan politik dari lembaga legislatif yang terlibat dalam penyusunan proses anggaran menyebabkan alokasi belanja modal terdistorsi dan sering tidak efektif dalam memecahkan masalah di masyarakat (Keefer dan Khemani, 2003 dalam Situngkir, 2009).

Darwanto dan Yustikasari (2007) menyatakan bahwa "Pemanfaatan anggaran belanja seharusnya dialokasikan untuk hal- hal produktif, misalnya untuk pembangunan. Oleh karena itu, penerimaan pemerintah daerah seharusnya dialokasikan untuk program- program layanan publik". Peningkatan kualitas pelayanan publik dapat diperbaiki melalui perbaikan manajemen kualitas jasa (service quality management), yakni upaya meminimalisasi kesenjangan (gap) antara tingkat layanan dengan dengan harapan konsumen (Bastian,2006). Dengan demikian, Pemerintah Daerah harus mengalokasikan anggaran daerah sesuai dengan kebutuhan dan aspirasi masyarakat sebagai salah satu pelayanan publik.

Anggaran belanja modal diperoleh dari berbagai sumber dana yang diterima oleh pemerintah daerah. Sumber dana yang diterima oleh pemerintah daerah terdiri dari pendapatan dan pembiayaan. Yang dimaksud dengan pendapatan adalah segala sumber dana yang berasal dari Pendapatan Asli Daerah, Dana Perimbangan, dan Lain-Lain 
Pendapatan. Lain-Lain Pendapatan disini contohnya adalah pendapatan Hibah dan Dana Darurat. Sedangkan yang dimaksud pembiayaan adalan segala sumber dana yang berasal dari Sisa Lebih Perhitungan Anggaran Daerah (SiLPA); penerimaan Pinjaman Daerah; Dana Cadangan Daerah; dan hasil penjualan kekayaan Daerah yang dipisahkan.

Anggaran Belanja Modal salah satunya digunakan untuk pembangunan desa. Pembangunan desa adalah upaya peningkatan kualitas hidup dan kehidupan untuk sebesar - besarnya kesejahteraan masyarakat desa. Provinsi Jawa Tengah kini sedang fokus untuk membangun desa agar lebih berpotensi dan mandiri. Gubernur Jawa Tengah Ganjar Pranowo mengharapkan seluruh jajaran aparat desa mengelola bantuan anggaran desa yang jumlahnya cukup besar itu dengan bertanggung jawab agar tidak terjerat pelanggaran hukum (beritajateng.net, 2015).

Pembangunan desa merupakan salah satu pemanfaatan dari anggaran pemerintah. Seperti yang dikutip dalam halaman CNN Indonesia, Kementerian Keuangan telah menetapkan seluruh desa yang tersebar di 29 kabupaten/kota Provinsi Jawa Tengah sebagai penerima alokasi dana desa terbesar dari Anggaran Pendapatan dan Belanja Negara Perubahan (APBNP) 2015. Alokasi dana desa yang ada di Provinsi Jawa Tengah tercatat sebesar Rp 2,23 triliun atau mencapai 10,73 persen dari total anggaran dana desa yang disiapkan pemerintah sebesar Rp 20,77 triliun.

Anggaran yang telah ditetapkan belum sepenuhnya mengurangi desa miskin di Jawa Tengah, masih banyak desa miskin yang belum mendapatkan perhatian dari pemerintah. Selain itu banyak sekali oknum nakal yang bermain dengan anggaran desa, contohnya adalah kasus korupsi yang dilakukan oleh salah satu bupati di Jawa Tengah yang telah menyalahgunakan dana desa untuk memperkaya dirinya. Ini menjadi salah satu faktor banyaknya desa yang belum bisa memperbaiki infrastrukturnya secara maksimal.Sehingga masih banyak desa yang tertinggal dan masuk dalam kategori desa miskin.

Kasus korupsi bukan menjadi salah satu penghambat pembangunan desa, adanya daerah yang belum memiliki perda dapat menjadi penghambat daerah dalam mengalokasikan dana untuk pembangunan desa, seperti yang disampaikan oleh Koordinator Advokasi dan Investigasi Forum Indonesia untuk Transparansi Anggaran (Fitra) Apung Widadi, beberapa Kabupaten seperti Rembang, Pati, dan Jepara belum memiliki payung hukum berupa perda maupun peraturan bupati untuk pengelolaan desa. "Kalau perda belum dibuat, pencairan dana desa akan terhambat. Sementara mereka harus menyusun laporan alokasi dana desa." Dengan demikian desa-desa yang berada didaerah tersebut belum dapat memperbaiki infrastruktur serta belum dapat mengembangkan kualitas desa (Liputan6.com, 2015).

Hal ini hendaknya menjadi pertimbangan bagi Pemerintah Daerah untuk dapat menggunakan anggaran desa dengan semaksimal mungkin agar tidak terdapat desa miskin di kabupaten/kota di Provinsi Jawa Tengah. Dana yang diberikan oleh pemerintah guna membangun daerah pedesaan tidak cukup tanpa adanya pendampingan dari pemerintah. Pendampingan dari pemerintah diharapkan dapat membantu meningkatkan kemandirian pada desa dan dapat memberdayakan masyarakat desa. Selain itu diharapkan masyarakat desa dapat mempertanggungjawabkan segala kegiatan dalam pembangunan desa maupun dalam pertanggungjawaban terhadap administrasi 
keuangan negara. Dengan demikian akan banyak desa yang mandiri dan jauh dari kemiskinan.

Dari uraian diatas terlihat bahwa pemerataan anggaran pada pembangunan desa masih belum maksimal. Pemerataan anggaran kepada setiap daerah di Provinsi Jawa Tengah masih belum baik. Beberapa peneliti telah meneliti tentang pendapatan asli daerah, diantaranya adalah Andreas Marzel Pelealu (2013), Ni Luh Selvia Martini, dkk (2014), Dini Arwati, dkk (2013), Yudi Satrya Aprizay , dkk (2014), Ida Mentayani, dkk (2013). Tetapi dari beberapa peneliti diatas memiliki pendapat yang berbeda mengenai pengaruh pendapatan asli daerah terhadap belanja modal. Belanja Modal di setiap daerah mempengaruhi kualitas layanan publik serta pada akhirnya dapat membangun minat publik untuk berpartisipasi pada pembangunan.Adakah keterkaitan antara Pendapatan Asli Daerah, Dana Perimbangan, serta Sisa Lebih Pembiayaan terhadap Belanja Modal.

\section{LANDASAN TEORI}

Teori Keagenan (Jensen dan Meckling, 1976 dalam Wertianti, 2013) menyatakan bahwa hubungan keagenan merupakan sebuah kontrak dimana satu atau lebih (prinsipal) melimpahkan wewenang kepada orang lain (agen) untuk kepentingan mereka. Studi-studi berkaitan dengan hubungan keagenan eksekutif-legislatif yang dilakukan para peneliti (lihat Thompson dan Jones, 1986; McCubbins et al., 1987; Christensen, 1992; Lupia, 2001; dan Fozzard, 2001) telah mengelompokkan keterkaitan akuntansi sektor publik dengan model hubungan keagenan ke dalam sistem pengawasan, manipulasi anggaran, informasi asimetri, dan sistem insentif antara eksekutif dan legislatif. Karenanya, sangat menarik untuk mengkaji lebih jauh hubungan keagenan eksekutif dan legislatif tersebut dalam proses anggaran pada pemerintahan daerah (Damayanti, 2009).

\section{Hubungan Keagenan antara Legislatif dan Publik ( Voters )}

Dalam hubungan keagenan ini, legislatif disebut sebagai agen dan publik sebagai prinsipal. Publik sebagai prinsipal telah memberikan sumber daya kepada daerah berupa pembayaran pajak, retribusi dan sebagainya untuk meningkatkan pendapatan daerah. Legislatif yang pada dasarnya adalah politisi yang telah dipilih oleh publik, seharusnya dalam mengenggarkan belanja daerah harus memberikan timbal balik kepada publik dengan cara memberikan pelayanan publik sesuai dengan kepentingan publik.

\section{Hubungan Keagenan antara Eksekutif dengan Legislatif}

Dalam hubungan keagenan antara eksekutif dan legislatif, legislatif mendelegasikan otoritas atau kewenangan kepada eksekutif sebagai expert agent untuk melaksanakan suatu tindakan (action) (Lupia \& McCubbins, 1994) dalam Asmara (2010). Dalam hubungan keagenan akan ada masalah antara prinsipal dan agen, sehingga masalah yang timbul antara eksekutif dan legislatif merupakan masalah keagenan. Wibawa (2005) dalam Damayanti (2012) menjelaskan bagi eksekutif mendengarkan suara rakyat yang tersalurkan melalui lembaga legislatif adalah sesuatu yang mustahil, membuang waktu dan tidak efisien. 


\section{Hubungan Keagenan dalam Anggaran Daerah}

Menurut Moe (1984) dalam Asmara (2010), terdapat berbagai hubungan keagenan dalam penganggaran di pemerintahan, yakni antara pemilih - legislatur, legislatur - pemerintah, menteri keuangan - pengguna anggaran, perdana menteri birokat, dan pejabat - pemberi pelayanan. Hubungan keagenan dalam sistem penganggaran, pemerintah pusat memberikan kewenangan kepada pemerintah daerah untuk mengurus semua kepentingan daerah, termasuk dalam membuat APBD. Anggaran yang dibuat pemerintah daerah digunakan untuk meningkatkan kualitas daerah dengan memaksimalkan pelayanan publik. Timbal balik dari pemerintah pusat adalah memberikan transfer dana perimbangan untuk membiayai segala kebutuhan daerah.

\section{Pengaruh Pendapatan Asli Daerah Terhadap Belanja Modal}

Penelitian tentang pengaruh pendapatan asli daerah terhadap belanja modal telah dilakukan oleh beberapa peneliti dengan kesimpulan bahwa pendapatan asli daerah berpengaruh terhadap belanja modal.Penelitian tersebut dilakukan oleh Pelealu (2013), Mentayani, dkk (2013).Dalam penelitian yang dilakukan oleh Pelealu (2013) dijelaskan bahwa PAD berpengaruh positif dan signifikan, PAD merupakan penerimaan daerah yang tidak memberikan kontribusi yang optimal terhadap belanja modal. Memaksimalkan PAD sebagai sumber penerimaan daerah yang akan membiayai pengeluaran pemerintah daerah lewat belanja modal, akan menarik para investor untuk menanamkan modalnya pada daerah yang nantinya akan menambah pendapatan asli daerah. Sedangkan dalam penelitian Mentayani, dkk (2013) menjelaskan bahwa PAD tidak berpengaruh terhadap belanja modal karena pendapatan asli daerah yang diperoleh belum optimal yang disebabkan keterbatasan kemampuan daerah mengeksplorasi hasil kekayaan alam dengan kemampuan sendiri. Dari hasil penjelasan diatas, maka hipotesis dalam penelitian ini :

H1: Diduga Pendapatan Asli Daerah berpengaruh signifikan terhadap Pengalokasian Belanja Modal pada Kabupaten/Kota di Provinsi Jawa Tengah

\section{Pengaruh Dana Perimbangan Terhadap Belanja Modal}

Penelitian tentang pengaruh dana perimbangan terhadap belanja modal telah dilakukan oleh beberapa peneliti dengan kesimpulan bahwa dana perimbangan berpengaruh terhadap belanja modal. Penelitian tersebut dilakukan oleh Aprizay, dkk (2014), Novianto, dkk (2015).Penelitian Aprizay (2014) menjelaskan bahwa terdapat hubungan antara dana perimbangan dengan belanja modal. Terdapat pengaruh yang negatif antara dana perimbangan dengan belanja modal, ini disebabkan karena pemda tidak mengalokasikan dengan baik penerimaan dana transfer pemerintah pusat terhadap belanja modal. Pemda lebih memilih memusatkan pengeluaran terhadap belanja rutin daerah yang tidak produktif. Sedangkan menurut Novianto, dkk (2015) menjelaskan bahwa DAU, DAK, DBH berpengaruh terhadap belanja modal. Dari penjelasan diatas, maka hipotesis dalam penelitian ini :

H2 : Diduga Dana Perimbangan berpengaruh signifikan terhadap Pengalokasian Belanja Modal pada Kabupaten/Kota di provinsi Jawa Tengah

\section{Pengaruh Sisa Lebih Pembiayaan Anggaran Terhadap Belanja Modal}

Penelitian tentang pengaruh sisa lebih pembiayaan anggaran terhadap belanja modal telah dilakukan oleh beberapa peneliti dengan kesimpulan bahwa sisa lebih 
pembiayaan anggaran berpengaruh terhadap belanja modal. Penelitian tersebut dilakukan oleh Mentayani, dkk (2013), Sugiarthi (2014).Penelitian Mentayani, dkk (2013) menjelaskan bahwa SiLPA berpengaruh terhadap belanja modal. SiLPA dimanfaatkan oleh kota dan kabupaten untuk belanja modal yang terdiri dari belanja tanah, peralatan dan mesin, gedung dan bangunan, jalan, irigasi dan jaringan, kontruksi dalam pengerjaan dan aset tetap lainnya. Hal yang sama dijelaskan oleh Sugiarthi (2014) bahwa SiLPA berpengaruh positif dan signifikan terhadap belanja modal, semakin tinggi SiLPA yang dimiliki oleh daerah maka semakin tinggi belanja modal yang dilakukan pemerintah. Dari penjelasan diatas, maka hipotesis dalam penelitian ini : H3 : Diduga Sisa Lebih Pembiayaan Anggaran berpengaruh signifikan terhadap Pengalokasian Belanja Modal pada Kabupaten/Kota di Provinsi Jawa Tengah

\section{METODE PENELITIAN}

Populasi dalam penelitian ini adalan seluruh kabupaten / kota yang ada di Provinsi Jawa Tengah yang berjumlah 35 daerah terdiri dari 29 kabupaten dan 6 kota.Sampel yang digunakan dalam penelitian ini sama dengan populasi penelitian, sehingga dalam penelitian ini menggunakan metode sensus sebagai metode penentuan sampel.Dalam penelitian ini objek penelitian dilakukan pada Laporan Realisasi APBD Pemerintah Kabupaten/Kota di Provinsi Jawa Tengah.Penelitian ini menggunakan data kuantitatif dan metode pengumpulan data yang dipakai adalah metode dokumentasi.Penelitian ini menggunakan data sekunder sebagai data yang dianalisis.Data sekunder yang dianalisis berasal dari Laporan Realisasi APBD Kabupaten / Kota di Provinsi Jawa Tengah.Laporan Realisasi APBD diperoleh melalui situs resmiDirektorat Jenderal Perimbangan Keuangan (DJPK) di www.djpk.depkeu.go.id. Dari laporan realisasi APBD didapat data mengenai jumlah realisasi belanja modal, pendapatan asli daerah (PAD), dana perimbangan, serta sisa lebih pembiayaan anggaran (SiLPA).

\section{Variabel Terikat}

Belanja Modal

Menurut Peraturan Pemerintah Republik Indonesia Nomor 71 Tahun 2010 adalah pengeluaran anggaran untuk perolehan aset tetap dan aset lainnya yang memberi manfaat lebih dari satu periode akuntansi.

\section{Variabel Bebas :}

a. Pendapatan asli daerah (PAD) merupakan semua penerimaan yang diperoleh daerah dari sumber-sumber dalam wilahnya sendiri yang dipungut berdasarkan peraturan daerah sesuai dengan peraturan perundang-undangan yang berlaku (Halim, 2004 ).

b. Dana Perimbangan merupakan Dana yang bersumber dari penerimaan Anggaran Pendapatan dan Belanja Negara (APBN) yang dialokasikan kepada daerah untuk membiayai kebutuhan daerah dalam rangka pelaksanaan desentralisasi (UU Nomor 25 tahun 1999).

c. Sisa Lebih/Kurang Pembiayaan Anggaran (SiLPA/SiKPA) adalah selisih lebih/kurang antara realisasi pendapatan-LRA dan belanja, serta penerimaan dan pengeluaran pembiayaan dalam APBN/APBD selama satuperiode pelaporan(Lampiran I.02 Peraturan Pemerintah Republik Indonesia No. 71 Tahun 2010). 


\section{Metode Analisis}

Metode analisis yang dipakai untuk menguji hipotesis penelitian adalah model regresi linier berganda (multiple linier regression model). Analisis regresi berganda mengestimasikan besarnya koefisien - koefisien yang dihasilkan oleh yang bersifat linier yang melibatkan dua variabel bebas untuk digunakan sebagai alat prediksi besarnya nilai variabel terikat (Sarwono, 2006).Ujiregresi berganda digunakan untuk menguji pengaruh pendapatan asli derah, dana perimbangan, dan sisa lebih pembiayaan anggaran terhadap belanja modal. Hubungan antar variabel tersebut dapat digambarkan dengan persamaan sebagai berikut :

$$
\begin{aligned}
& \mathrm{BM}=\alpha+\beta 1 \mathrm{PAD}+\beta 2 \mathrm{DP}+\beta 3 \mathrm{SiLPA}+\mathrm{e} \\
& \text { dimana : } \\
& \alpha \quad=\text { konstanta } \\
& \beta \mathrm{i} \quad=\text { koefisiean regresi } \\
& \mathrm{BM}=\text { Belanja Modal } \\
& \text { PAD = Pendapatan Asli Daerah } \\
& \mathrm{DP} \quad=\text { Dana Perimbanga } \\
& \text { SiLPA }=\text { Sisa Lebih Pembiayaan Anggaran } \\
& \text { e } \quad=\text { error }
\end{aligned}
$$

Sebelum melakukan analisis regresi berganda, dilakukan analisis statistik

\begin{tabular}{|c|c|c|c|c|c|}
\hline & $\mathrm{N}$ & Minimum & Maximum & Mean & Std. Deviation \\
\hline PAD & 175 & 32238,00 & 925919,00 & 116087,5143 & 100266,02871 \\
\hline DP & 175 & 94271,00 & 1384770,00 & 738238,2343 & 228954,65897 \\
\hline SiLPA & 175 & 19956,00 & 635458,00 & 100179,1543 & 73540,29731 \\
\hline $\mathrm{BM}$ & 175 & 25479,00 & 591011,00 & 148330,1943 & 80959,73419 \\
\hline $\begin{array}{ll}\text { Valid } & \mathrm{N} \\
\text { (listwise) } & \end{array}$ & 175 & & & & \\
\hline
\end{tabular}
deskriptif, uji normalitas data dan uji asumsi klasik.

\section{HASIL PENELITIAN}

\section{Analisis Statistik Deskriptif}

Hasil pengamatan PAD, DP, SiLPA, dan Belanja Modal di Provinsi Jawa Tengah dengan jumlah data pengamatan sebanyak 175 menunjukkan hasil dari analisis statistik deskriptif sebagai berikut :

Tabel 4.1

Hasil Analisis Statistik Deskriptif

Sumber : Output SPSS,2016 


\section{Uji Asumsi Klasik \\ Uji Normalitas}

Hasil Uji K-S menunjukkan besarnya nilai Kolmogorov-Smirnov adalah 1,244 dan signifikan pada 0,091 ini berarti nilai signifikan diatas 5 persen. Hal ini berarti H0 diterima yang berarti data residual terdistribusi normal.

\section{Uji Multikolonieritas}

Hasil Uji Multikolonieritas menunjukkan tidak terdapat variabel independen yang memiliki nilai tolerance kurang dari 0,10 yang berarti tidak ada korelasi antar variabel independen. Sedangkan hasil perhitungan nilai VIF juga menunjukkan hal yang sama, tidak ada satu variabel yang memiliki nilai VIF lebih dari 10. Jadi dapat disimpulkan bahwa tidak ada multikolonieritas antar variabel independen dalam model regresi.

\section{Uji Heteroskedastisitas}

Hasil Uji Glejser menunjukkan tidak ada satupun variabel independen yang signifikan secara statistik mempengaruhi variabel dependen. Hal ini terlihat dari nilai probabilitas signifikansinya diatas tingkat kepercayaan 5 persen. Jadi dapat disimpulkan model regresi tidak mengandung adanya heteroskedastisitas.

\section{Uji Autokorelasi}

Hasil Uji Autokorelasi bahwa nilai test adalah - 8077,17670 dengan probabilitas 0,150 signifikan pada 0,05 yang berarti hipotesis nol diterima, sehingga dapat disimpulkan bahwa residual random atau tidak terjadi autokorelasi antar nilai residual.

\section{Analisis Linier Berganda}

Dari hasil perhitungan, maka dapat disusun persamaan regresi berganda sebagai berikut :

BM : -1144,434 + 0,302PAD + 0,133DP + 0,091SiLPA + e

Hasil persamaan pada variabel PAD, DP, dan SiLPA menuju pada arah koefisien positif. Dapat disimpulkan bahwa kenaikan PAD, DP, dan SiLPA dapat meningkatkan Belanja Modal.

\section{Koefisien Determinasi}

Hasil koefisien determinasi $\left(\mathrm{R}^{2}\right)$ menunjukkan besarnya adjusted $\mathrm{R}^{2}$ adalah 0,575 hal ini berarti 57,5 persen variasi Belanja Modal dijelaskan oleh variasi dari tiga variabel independen PAD, DP, SiLPA. Sedangkan sisanya $(100 \%-57,5 \%=42,5 \%)$ dijelaskan oleh sebab-sebab yang lain diluar model. Sebab-sebab ini dapat berupa penerimaan daerah lainnya seperti pinjaman daerah dan lain-lain pendapatan daerah yang sah, ataupun sebab yang lain non keuangan seperti kebijakan pemerintah maupun pertumbuhan ekonomi di daerah tersebut.

\section{U.ji F}

Hasil Uji $\mathrm{F}$ menunjukkan bahwa nilai $\mathrm{F}$ hitung sebesar 79,358 dengan probabilitas 0,000. Ini berarti probabilitas jauh lebih kecil dari 0,05. F hitung sebesar 79,358 > F tabel sebesar 2,66 maka Ho diterima dengan demikian dapat disimpulkan 
bahwa PAD,DP, dan SiLPA secara simultan berpengaruh signifikan terhadap Belanja Modal.

Hasil Uji t menunjukkan bahwa :

1. Untuk hasil Uji t terhadap PAD didapat hasil t hitung sebesar 5,105 dengan signifikansi sebesar 0,000. Nilai signifikansi untuk variabel PAD menunjukkan nilai dibawah signifikansi $0,000<0,05$. Sedangkan nilai t hitung 5,105 $>\mathrm{t}$ tabel 1,974 maka Ho ditolak sehingga ada pengaruh yang signifikan PAD terhadap belanja modal.

2. Untuk hasil Uji t terhadap DP didapat hasil t hitung sebesar 5,989 dengan signifikansi sebesar 0,000. Nilai signifikansi untuk variabel DP menunjukkan nilai dibawah signifikansi $0,000<0,05$. Sedangkan nilai t hitung 5,989 $>\mathrm{t}$ tabel 1,974 maka Ho ditolak sehingga ada pengaruh yang signifikan DP terhadap belanja modal.

3. Untuk hasil Uji t terhadap SiLPA didapat hasil t hitung sebesar 1,761 dengan signifikansi sebesar 0,080. Nilai signifikansi untuk variabel SiLPA menunjukkan nilai diatas signifikansi $0,080>0,05$. Sedangkan nilai t hitung 1,761 $<\mathrm{t}$ tabel 1,974 maka Ho diterima sehingga tidak ada pengaruh yang signifikan SiLPA terhadap belanja modal.

\section{Pengaruh PAD terhadap Belanja Modal}

Hasil pengujian hipotesis menunjukkan bahwa PAD berpengaruh signifikan terhadap pengalokasian belanja modal. Ini terlihat dari nilai t hitung yang lebih besar dari t tabel $(5,105>1,974)$ dengan nilai signifikansi lebih besar dari nilai $\alpha=5 \%(0,000$ $<$ 0,05). Dengan demikian dapat disimpulkan bahwa pendapatan asli daerah di kabupaten/kota di provinsi Jawa Tengah selama kurun waktu 5 tahun telah memberikan dampak yang besar pada penerimaan daerah. Dan memberikan distribusi yang besar terhadap pengalokasian belanja modal dalam meningkatkan sarana dan prasarana daerah dalam mewujudkan pelayanan publik.

Hasil yang sama diungkapkan oleh Pelealu (2013), bahwa Pendapatan Asli Daerah berpengaruh signifikan terhadap belanja modal. Pelealu (2013) menyebutkan bahwa memaksimalkan PAD sebagai sumber penerimaan daerah yang akan membiayai pengeluaran pemerintah daerah lewat belanja modal, akan menarik para investor untuk menanamkan modalnya pada daerah yang nantinya akan menambah pendapatan asli daerah. Dengan begitu peningkatan investasi modal diharapkan juga mampu meningkatkan kualitas publik dan pada gilirannya mampu meningkatkan tingkat partisipasi publik terhadap pembangunan yang tercermin dari adanya peningkatan PAD. Hal berbeda diungkapkan oleh Mentayani, dkk (2013) yang menyebutkan bahwa PAD tidak berpengaruh signifikan terhadap belanja modal. Hal ini disebabkan karena adanya perbedaan pada sampel dan periode penelitian.

\section{Pengaruh Dana Perimbangan terhadap Belanja Modal}

Hasil pengujian hipotesis menunjukkan bahwa Dana Perimbangan (DP) berpengaruh signifikan dengan pola positif terhadap belanja modal. Ini terlihat dari nilai t hitung yang lebih besar dari t tabel $(5,989>1,974)$ dengan nilai signifikan lebih kecil dari nilai $\alpha=5 \%(0,000<0,05)$. Hasil hipotesis yang menunjukkan berpola positif, dapat diartikan bahwa dana perimbangan yang ditransfer ke daerah jika dana tersebut 
mengalami kenaikan maka belanja modal juga akan mengalami kenaikan. Dalam pembangunan sarana dan prasarana daerah, pemerintah masih bergantung pada dana transfer dari pemerintah pusat. Pemerintah daerah dapat mengalokasikan dana perimbangan dengan baik sehingga dapat mewujudkan pembangunan daerah yang baik dengan tujuan sebagai pelayanan publik.

Hasil yang sama diungkapkan oleh Aprizay, dkk (2014) bahwa Dana Perimbangan berpengaruh terhadap belanja modal tetapi berpola negatif. Aprizay, dkk (2014) menjelaskan hal tersebut terjadi disebabkan karena pemerintah daerah tidak mengalokasikan dengan baik penerimaan dana tranfer pemerintah pusat terhadap belanja modal. Pemerintah daerah memilih memusatkan pengeluaran terhadap belanja rutin daerah yang tidak produktif.

\section{Pengaruh SiLPA terhadap Belanja Modal}

Hasil pengujian hipotesis menunjukkan bahwa Sisa Lebih Pembiayaan Anggaran tidak berpengaruh signifikan terhadap pengalokasian belanja modal. Ini terlihat dari nilai $t$ hitung yang lebih kecil dari t tabel $(1,761<1,974)$ dengan nilai signifikan lebih besar dari nilai $\alpha=5 \%(0,080>0,05)$. Dengan demikian dapat disimpulkan bahwa sisa lebih pembiayaan anggaran dalam kurun waktu 5 tahun tidak dapat memberikan dampak pada penerimaan daerah. SiLPA tidak dapat berperan dalam pembangunan sarana dan prasarana daerah melalui belanja modal. Hal ini menunjukkan pemerintah daerah belum berhasil menggunakan SiLPA untuk melaksanakan program pembangunan daerah sebagai salah satu pelayanan publik.

Menurut Riyanto (2012), mengungkapkan bahwa ada ketergantungan penerimaan pembiayaan daerah Jawa Tengah dari pendapatan SiLPA tahun lalu. Namun Riyanto berpendapat bahwa realisasi belanja daerah selalu dibawah target perencanaan penganggaran sehingga menghasilkan angka SiLPA tahun berkenan yang selalu naik. Belanja daerah dalam realisasi APBD lebih besar untuk biaya belanja rutin daripada belanja pelaksanaan program dan kegiatan pembangunan, serta lebih menekankan alokasi barang dan jasa yang habis pakai daripada alokasi untuk pembangunan infrastruktur atau belanja investasi (belanja modal).

Hal ini berbanding terbalik dengan penelitian yang dilakukan oleh Sugiarthi (2014) yang mengungkapkan bahwa SiLPA berpengaruh terhadap belanja modal. Sugiarthi (2014) mengungkapkan semakin tinggi SiLPA yang dimiliki semakin tinggi belanja modal yang dilakukan pemerintah. Hal tersebut terjadi dikarenakan sampel dan periode dalam penelitian berbeda.

\section{PENUTUP Simpulan}

Berdasarkan hasil penelitian dan pembahasan, maka dapat diambil simpulan bahwa terdapat pengaruh antara Pendapatan Asli Daerah dan Dana Perimbangan terhadap Belanja Modal pada kabupaten/kota di Provinsi Jawa Tengah, sedangkan Sisa Lebih Pembiayaan Anggaran tidak berpengaruh terhadap Belanja Modal pada kabupaten/kota di Provinsi Jawa Tengah.

Saran dalam penilitian ini, diharapkan pemerintah dapat meningkatkan PAD dengan cara mengoptimalkan potensi yang dimiliki daerah sebagai sumber penerimaan daerah yang dapat membiayai pengeluaran pemerintah daerah lewat belanja modal, 
menambah anggaran DP yang dialokasikan untuk anggaran belanja modal, dan memperhatikan SiLPA karena sangat menentukan kemampuan pemerintah daerah dalam memperkirakan besarnya pendapatan dan belanja modal. Sebaiknya SiLPA tidak hanya dimanfaatkan untuk belanja pegawai tapi dapat lebih dimanfaatkan untuk pembelian aset daerah.

Keterbatasan dalam penelitian ini adalah sampel pada penelitian ini hanya berfokus pada Provinsi Jawa Tengah serta terbatas pada periode 2009 sampai 2013.Diharapkan untuk peneliti selanjutnya dapat menambah sampel yang lebih luas tidak hanya terbatas pada Provinsi Jawa Tengah sehingga dapat memberikan hasil yang lebih sesuai dengan kenyataan sebenarnya dan menambah periode pengamatan dengan minimal diatas 5 tahun. 


\section{DAFTAR PUSTAKA}

Abdul Halim dan Syukriy Abdullah. 2006. Studi atas Belanja Modal Pada Anggaran Pemerintah Daerah dalam Hubungannya dengan Belanja Pemeliharaan dan Sumber Pendapatan. Jurnal Akuntasi Pemerintah. No.2. Volume 2.

Abdullah, Syukry, dan Abdul Halim. 2003. Pengaruh Dana Alokasi Umum (DAU) dan Pendapatan Asli Daerah (PAD) Terhadap Belanja Pemerintah Daerah:Studi Kasus Kabupaten/Kota di Jawa dan Bali. Simposium Nasional Akuntansi Surabaya Oktober 2003.

Aprizay, Yudi Satrya; Darwanis dan Arfan, Muhammad. 2014. “ Pengaruh Pendapatan Asli Daerah, Dana Perimbangan dan Sisa Lebih Pembiayaan Anggaran Terhadap Pengalokasian Belanja Modal pada Kabupaten/Kota di Provinsi Aceh". Jurnal Akuntansi. Volume 3. No.1.

Arwati, Dini, dan Novita Hadiati. 2013. "Pengaruh Pertumbuhan Ekonomi, Pendapatan Asli Daerah dan Dana Alokasi Umum Terhadap Pengalokasian Anggaran Belanja Modal pada Pemerintah Daerah Kabupaten/Kota di Propinsi Jawa Barat". Seminar Nasional Teknologi Informasi dan Komunikasi Terapan 2013 (SEMANTIK 2013). 498-507

Asmara, Jhon Andra. 2010. Analisis Perubahan Alokasi Belanja Dalam Anggaran Pendapatan dan Belanja Daerah ( APBA ) Provinsi Nanggroe Aceh Darussalam. Jurnal Telaah \& Riset Akuntansi. Volume 3. No. 2.

Bastian, Indra. 2003. Sistem Akuntansi Sektor Publik: Konsep Untuk Pemerintah Daerah. Jakarta: Salemba Empat.

Bastian, Indra. 2006. Sistem Akuntansi Sektor Publik. Salemba Empat. Jakarta.

Damayanti, Ratna Ayu. 2009. " Hubungan Keagenan Pemerintahan Daerah Dalam Konteks Anggaran : Sebuah Agenda Rekonstruksi “. Ekuitas Vol. 15 No. 2. ISSN 1411-0393

Darwanto dan Yulia Yustikasari. 2007. " Pengaruh Pertumbuhan Ekonomi, Pendapatan Asli Daerah dan Dana Alokasi Umum Terhadap Pengalokasian Anggaran Belanja Modal”. Simposium Nasional Akuntansi X. Makasar. 26-28 Juli 2007

Ghozali, Imam. 2011. Aplikasi Analisis Multivariate dengan program IBM SPSS 19.

Edisi Kelima. BP Universitas Diponegoro. Semarang.

Halim, Abdul. 2002. Akuntansi Keuangan Daerah, Edisi 3 Akuntansi Sektor Publik. Salemba Empat. Jakarta

Halim. 2004. " Pengaruh Dana Alokasi Umum Dan Pendapatan Asli Daerah Terhadap Belanja Pemda : Studi Kasus Kabupaten dan Kota di Jawa dan Bali”.

Jurnal Ekonomi STEI. No. 2/Tahun XIII/25

http://beritajateng.net/berita-jateng-terbaru-hari-ini/anggaran-desa-cair-januari 2015/1074 , Diakses pada Sabtu, 21 November 2015, Pukul 10.55

http://dispenda.inhukab.go.id/web/detailberita/189, Diakses pada Senin, 26 Oktober 2015, Pukul 13.49

http://news.liputan6.com/read/2226204/fitra-program-dana-desa-potensial-ditunggangimafia, Diakses pada Kamis, 15 Oktober 2015, Pukul 10.26

http://regional.kompas.com/read/2015/11/17/19562621/Ganjar.akui.Infrastruktur.Jateng. Jauh.Tertinggal, Diakses pada Sabtu, 21 November 2015, Pukul 12.00 
http://www.cnnindonesia.com/ekonomi/20150401110321-78-43448/jawa-tengahdapat-dana-desa-besar-karena-banyak-orang-miskin/. Diakses pada Minggu, 11 Oktober 2015, Pukul 22.08

Mamuka, Veronika dan Elim, Inggriani. 2014. “ Analisis Dana Transfer Pada Pemerintah Daerah Kabupaten Kepulauan Talaud”. Jurnal EMBA. Vol. 2 No. 1. Hal. 646 - 655

Martini, Ni Luh Selvia; Cipta, Wayan dan Suwendra, I Wayan. 2014. " Pengaruh Pendapatan Asli Daerah, Dana Alokasi Umum dan Dana Alokasi Khusus Terhadap Belanja Modal Pada Kabupaten Buleleng Tahun 2006-2012”. Ejurnal Bisma Universitas Pendidikan Ganesha. Volume 2

Mentayani, Ida dan Rusmanto. 2013. “Pengaruh Pendapatan Asli Daerah, Dana Alokasi Umum dan Sisa Lebih Pembiayaan Anggaran Terhadap Belanja Modal pada Kota dan Kabupaten di Pulau Kalimantan". Jurnal InFestasi. Volume 9. No.2

Novianto, Riko dan Rafiudin Hanafiah. 2015. "Pengaruh Pendapartan Asli Daerah, Dana Perimbangan, dan Kinerja Keuangan Terhadap Alokasi Belanja Modal Pada Pemerintah Kabupaten/Kota di Provinsi Kalimantan Barat". Jurnal Ekonomi. No. 1. Volume 4

Pelealu, Andreas Marzel. 2014. “Pengaruh Dana Alokasi Khusus ( DAK ), dan Pendapatan Asli Daerah ( PAD ) Terhadap Belanja Modal Pemerintah Kota

Manado Tahun 2003- 2012”. Jurnal EMBA. Volume 1. No.4

Peraturan Menteri Dalam Negeri No. 13 Tahun 2006. Tentang Pedoman Pengelolaan Keuangan Daerah

Peraturan Menteri Keuangan Nomor 92/PMK.05/2011 tentang Rencana Bisnis dan Anggaran serta Pelaksanaan

Peraturan Pemerintah Republik Indonesia No. 55 Tahun 2005. Tentang Dana Perimbangan

Peraturan Pemerintah Republik Indonesia No. 58 Tahun 2005. Tentang Pengelolaan Keuangan Daerah

Peraturan Pemerintah Republik Indonesia No. 71 Tahun 2010. Standar Akuntansi Daerah

Riyanto, Agus. 2012. "Politik Anggaran Provinsi Jawa Tengah : Analisis Realisasi APBD Provinsi Jawa Tengah Tahun Anggaran 2008-2010 ”. Jurnal Ilmu Politik Hubungan Internasional. Vol.12. No.2. Juli 2012

Salinan Peraturan Menteri Keuangan Nomor 206/PMK.05/2010 tentang Pengelolaan Saldo Anggaran Lebih.

Sarwono, Jonathan. 2006. Metode Penelitian Kuantitatif dan Kualitatif. Yogyakarta:Graha Ilmu

Sidik, Machfud, B. Raksana Mahi, Robert Simanjuntak, \& Bambang Brojonegoro, 2002, Dana Alokasi Umum-Konsep Hambatan, dan Prospek di Era Otonomi Daerah, Penerbit Buku Kompas, Jakarta.

Situngkir, Anggiat. 2009. "Pengaruh Pertumbuhan Ekonomi, Pendapatan Asli Daerah, Dana Alokasi Umum, Dan Dana Alokasi Khusus Terhadap Anggaran Belanja Modal Pada Pemko/Pemkab Sumatera Utara". Tesis. Universitas Sumatera Utara. Medan

Subekan, Achmat 2012. - Keuangan Daerah : Terapi Atasi Kemiskinan\|. Dioma, Malang 
Sugiarthi, Ni Putu Dwi Eka Rini dan Supadmi, Ni Luh. 2014. "Pengaruh PAD, DAU, SiLPA Pada Belanja Modal Dengan Pertumbuhan Ekonomi Sebagai Pemoderasi”. E - Jurnal Akuntansi Universitas Udayana. ISSN : 2302 - 8556. Hal $477-495$.

Sugiyono. 2010. Metode Penelitian Kuantitatif, Kualitatif dan R \& D. CV.Alfabeta:Bandung.

Undang - Undang No. 25 Tahun 1999 Tentang Perimbangan Keuangan Antara Pemerintah Pusat dan Pemerintahan Daerah.

Undang - Undang Republik Indonesia No. 33 Tahun 2004. Tentang Perimbangan Keuangan Antara Pemerintah Pusat dan Pemerintah Daerah

Undang - Undang Republik Indonesia No. 28 Tahun 2009. Tentang Pajak Daerah dan Retribusi Daerah

Undang - Undang No. 27 Tahun 2014. Tentang Anggaran Pendapatan dan Belanja Negara Tahun Anggaran 2015

Website Direktorat Jenderal Perimbangan Keuangan yang diakses melalui www.djpk.depkeu.go.id

Website Badan Pusat Statistik diakses melaluiwww.bps.go.id

Wertianti, I G A Gede dan A.A.N.B Dwirandra. 2013. " Pengaruh Pertumbuhan Ekonomi Pada Belanja Modal Dengan PAD dan DAU sebagai Variabel Moderasi”. E-jurnal Akuntansi Universitas Udayana 4.3. ISSN: 2302- 8556 